\title{
Effect of Age Structure on the Outcome of Viral Epizootics in Field Populations of Imported Cabbageworm (Lepidoptera: Pieridae)
}

\author{
SUSAN E. WEBB ${ }^{1}$ AND ANTHONY M. SHELTON
}

\author{
Department of Entomology, New York State Agricultural Experiment Station, \\ Geneva, New York 14456
}

\begin{abstract}
Environ. Entomol. 19(1): 111-116 (1990)
ABSTRACT The effect of larval age on the progress of epizootics of a granulosis virus was examined in field populations of imported cabbageworm, Artogeia rapae (L.), in 1985 and 1986. An enzyme-linked immunosorbent assay (ELISA) was used to follow the progress of disease in three larval age classes beginning 2-3 d after treatment. On virus-treated cabbage, late second and early third instars were more liable to infection than were first and final instars. In laboratory experiments, potted cabbage plants were treated with virus in the same way that field plots had been, and leaves were fed to three age classes of larvae at three temperatures for 18-23 h. Fewer larvae developed disease when given access to leaves at $16^{\circ} \mathrm{C}$ than at 22 or $28^{\circ} \mathrm{C}$. Fewer first instars became infected than third and fifth instars. Third instars were most likely to become infected at all temperatures. The data suggest that virus should be directed at second and third instars rather than at larvae at hatching.
\end{abstract}

KEY WORDS Insecta, granulosis virus, Artogeia rapae, enzyme-linked immunosorbent assay

THE IMPORTED CABBAGEWORM, Artogeia rapae (L.), can be controlled with a granulosis virus (Kelsey 1958, Wilson 1960, Jaques 1977, Sears et al. 1983). As with most biological insecticides, however, the effectiveness of the virus at a particular time and place depends on weather, distribution of virus and host, susceptibility of the host, and the infectivity of the virus. Infected insects may live for a week or more and continue to feed during this time (Harper 1973, Tatchell 1981); thus, proper timing of treatments is essential to prevent unacceptable damage to the crop.

In general, susceptibility to baculoviruses in Lepidoptera decreases as larvae age (Payne et al. 1981, Teakle et al. 1985a, Evans 1986). In some cases, feeding behavior dictates the timing of treatments, as with Heliothis virescens (F.) on cotton; older larvae feed in protected sites on the plant. Potter \& Watson (1983) obtained good control of this pest if they timed applications of a nuclear polyhedrosis virus to coincide with hatching of eggs, but not at earlier or later times. For A. rapae, the potential for greater damage by older larvae (Tatchell 1981), combined with their lower susceptibility to infection, has led to the recommendation that applications of virus be directed against the youngest larvae (David 1975).

Higher feeding rates may, however, compensate for the greater resistance to infection in older larvae by increasing the amount of virus the insects acquire. Teakle et al. (1985b) found that for the first

\footnotetext{
' Current address: University of Florida, IFAS, CFREC, 5336 University Ave., Leesburg, Fla. 32748.
}

three instars of Heliothis armigera (Hübner), increased acquisition did counteract increasing resistance to infection. Payne et al. (1981) suggested that for A. rapae, a decreasing susceptibility to granulosis virus would be compensated for by the increased feeding rates of older larvae.

In this study, we followed the progress of epizootics of granulosis virus in three age classes of $A$. rapae to determine if compensation was occurring. We also needed information on susceptibility in the field to refine a threshold for timing treatments based on pest density. In laboratory studies, we examined the effect of age and temperature on virus acquisition.

\section{Materials and Methods}

Experimental Design. Field experiments were conducted at the Robbins Vegetable Research Farm, Geneva, N.Y., in fields previously untreated with granulosis virus. In 1985, three treatments and an untreated control were arranged in a randomized complete block design with four blocks. Treatments consisted of three age classes of $A$. rapae larvae: newly hatched, late second and early third instars, and late fourth and early fifth instars. The control plots contained newly hatched larvae, the stage that is most susceptible to viral infection in laboratory bioassays. Each of the 16 plots consisted of eight rows spaced $1.0 \mathrm{~m}$ apart, each containing 12 cabbages spaced $0.5 \mathrm{~m}$ apart. Plots were $6 \mathrm{~m}$ apart with sudangrass planted between plots to pre- 
vent spread of virus to check plots and to adjacent field experiments. Cabbage seedlings ('Roundup') were transplanted on 26 and 27 June 1985. In 1986, the experiment was repeated but with three blocks per treatment. Cabbage was transplanted on 19 June. Although plots were still $6 \mathrm{~m}$ apart, sudangrass barriers were not planted because they had proved unnecessary for preventing primary infections because of spray drift and were ineffective in preventing secondary spread of virus in 1985

Establishment of Age Classes. Beginning at the end of July in 1985 and in mid-July in 1986, we stapled Parafilm strips bearing eggs from a laboratory colony of $A$. rapae to the undersides of middle-to-upper frame leaves of cabbage plants where butterflies normally deposit their eggs. We had found in preliminary studies that it was necessary to use 25-50 eggs per plant to obtain 5-12 fourth instars per plant, allowing for infertile eggs, cannibalism, predation, and other losses.

To estimate the data of virus application and the dates on which we would need to infest plants, we used weather forecasts that predicted average temperatures for a week in advance. Using the average degree-day accumulation above the appropriate base temperature as reported by Tatchell (1981), we estimated when larvae would molt from one instar to the next. For example, if the average temperature was $21.6^{\circ} \mathrm{C}$, eggs would hatch on day 3 , larvae would molt to the second instar on day 8 or 9 and to the fourth instar on day 12 or 13. Thus, we could obtain three age classes by infesting individual plots 12,8 , and $3 \mathrm{~d}$ before treatment (i.e., with four blocks, four plots were infested on day 3 , four on day 8 , and four on day 12). In practice, we fine-tuned this process by checking (on a daily basis) development of larvae in plots, actual temperatures from the Geneva weather station, and weather forecasts.

We relied on the natural population for the youngest age class for the last infestation in 1986 because we did not have sufficient eggs from the laboratory colony. There were, however, enough eggs to infest one of the check plots, so that the application of virus could be timed to coincide with hatching of these eggs. In plots artificially stocked with eggs (oldest and intermediate classes), it was a simple matter to judge which larvae were the appropriate size to collect; the natural population was low (judging from the uninfested plots), and infested plots had as many as 20 larvae per plant, especially those containing the intermediate age class. To estimate the upper and lower size limits of larvae to be collected in the youngest age class from the natural population, we used the one check plot that contained the youngest age class (healthy larvae from laboratory colony eggs) to estimate the upper size limit, and laboratory-infected larvae (because infected larvae cease molting and there: were no infected larvae in the check plots for comparison) to estimate the lower size limit. This was unnecessary in 1985 because we could assume that almost all larvae on a plant had hatched from laboratory colony eggs.

Application of Virus. When larvae reached the appropriate age, all treatments were sprayed with an aqueous suspension of granulosis virus $(2.6 \times$ $10^{10}$ occlusion bodies [OBs]/liter) with $15 \mathrm{~g} /$ liter of skim milk powder added to protect against ultraviolet inactivation and $0.75 \mathrm{ml} /$ liter of spreader sticker (Agway, Syracuse, N.Y.) to improve coverage and adherence to the waxy leaves of cabbage. A $\mathrm{CO}_{2}$-powered backpack sprayer was used to apply the virus suspension ( 498 liters/ha or $1.3 \times 10^{13}$ $\mathrm{OBs} / \mathrm{ha}$ ). Plots were treated at dusk so that larvae would feed on contaminated foliage before the virus was exposed to sunlight.

Collection of Larvae for ELISA. In 1985, we sampled daily from day 3 to 7 after treatment. Thirty larvae were collected from each replicate (plot) and placed together in a waxed paper carton. A few pieces of untreated cabbage leaf were added to provide food and a substrate for the larvae, which helped prevent injury during transport and which also kept larvae separated when frozen. Larvae were stored immediately at $-20^{\circ} \mathrm{C}$ upon return to the laboratory. On the fifth day of sampling, symptoms of viral disease were becoming pronounced, and we switched to destructively sampling 16 plants per plot, collecting all larvae from each plant, to avoid sampling bias.

In 1986, we began sampling larvae $1 \mathrm{~d}$ earlier, destructively sampling $10-15$ plants per plot and collecting all larvae for each plant. Larvae from each plot were pooled and frozen. Forty larvae randomly chosen from the bulked sample were tested from each plot for each day.

ELISA. Because of difficulties associated with rearing field-collected $A$. rapae in the laboratory (Webb 1988), we used the double antibody sandwich enzyme-linked immunosorbent assay (DAS ELISA) to detect viral infections. DAS ELISA will detect as little as $2.5 \mathrm{ng}$ of purified granulosis virus in the presence of host tissue; infections can be detected $48 \mathrm{~h}$ after infection in larvae reared at $21^{\circ} \mathrm{C}$ (Webb 1988). If larvae contained enough virus to test positive in ELISA, we assumed that they would have eventually died from the infection.

The DAS ELISA was performed essentially as described by Clark \& Adams (1977) but with some modifications (Webb 1988). Frozen larvae were sorted approximately by size in groups of 3-8 larvae and weighed. Using the average weight per larva calculated from the weight of the group, we calculated the volume of extraction buffer $(0.02 \mathrm{M}$ phosphate-buffered saline, $\mathrm{pH} 7.4$, containing $0.5 \%$ Tween 20 [PBST]) required for homogenizing individual larvae. Larvae averaging $>10 \mathrm{mg}$ each were diluted 1:50 (wt/wt), larvae weighing $>2 \mathrm{mg}$ but $<10 \mathrm{mg}$ were diluted 1:200, and larvae weighing $<2 \mathrm{mg}$ were diluted 1:500 to have a minimum sample volume of $400 \mu \mathrm{l}$ for each larva, enough for two wells in the microtiter plate used for the assay. Preliminary tests showed that this assay could 
detect the virus at these dilutions. For very small larvae (i.e., those weighing less than $0.8 \mathrm{mg}$ ), we reduced volumes for all steps of the ELISA to 100 $\mu \mathrm{l}$.

For any given sampling date, larvae in a particular treatment (age class) were similar in weight, and each replicate of 30-40 larvae was tested at one dilution in the same ELISA plate with 6-8 negative controls (individual fifth instars reared on broccoli plants in the greenhouse, collected and stored at $-20^{\circ} \mathrm{C}$ until needed). A standard positive control was prepared by homogenizing, in $150 \mathrm{ml}$ of PBST, $3 \mathrm{~g}$ of fifth instars that had been fed viruscontaminated leaf disks $4 \mathrm{~d}$ earlier. The homogenate was stored at $-20^{\circ} \mathrm{C}$ in $3-\mathrm{ml}$ aliquots that were thawed and diluted as needed.

Results were summarized as percentage of infection; arcsine-transformed percentages were analyzed using a repeated measures method contained in the SAS GLM procedure (SAS Institute 1985). Orthogonal contrasts were used to compare differences among treatments based on the overall disease progress curve, and on the first and last sampling dates.

Interaction of Temperature and Larval Age. Using the $\mathrm{CO}_{2}$-powered backpack sprayer that was used in the field experiment, we treated 12 4-moold potted cabbage plants with the virus suspension described previously. The plants, treated at dusk, were allowed to dry until the next morning. Four or five middle-to-upper frame leaves were picked from each plant. Leaves from untreated plants were used as controls. Twenty-five to $30 \mathrm{first}$, third, or fifth instars were placed on two virus-treated leaves in a clear plastic box ( 26.5 by 33 by $10 \mathrm{~cm}$ ). One leaf was placed with the abaxial surface up and the other with the abaxial surface down. Larvae moved freely over both sides of the leaves before settling to feed. Three groups of each instar (only two of the three replicates of first instars at each temperature were used in the analysis because of poor survival in one of the replicates) were held at each of three temperatures $\left(16,22\right.$, and $\left.28^{\circ} \mathrm{C}\right)$ with a photoperiod of 16:8 (L:D). In the first experiment, larvae were transferred to fresh, untreated leaves after $18 \mathrm{~h}$ and reared at $28^{\circ} \mathrm{C}$ (to hasten symptom development) until definite symptoms of granulosis virus infection developed 4-5 d later.

Because virus on the leaves was protected from the inactivating effects of sunlight, we used an acquisition period of $18-23 \mathrm{~h}$ to mimic what might happen under field conditions (in which less than $30 \%$ of viral activity remains after $48 \mathrm{~h}$ [S.E.W., unpublished data]). As the results of our field experiment show (see Results), infections developing from initial virus applications became detectable over a narrow span of time, suggesting that the majority of larvae ingested a lethal dose over a similarly brief interval.

Two months later, the same group of plants was treated again. Plants had been left outside since the first treatment and had been occasionally at- tacked by $A$. rapae and cabbage loopers, Trichoplusia ni (Hübner). These wild larvae were not observed for infection, however. Controls consisted of plants treated 2 mo earlier but not re-treated (we assumed that no infectious virus would remain after $2 \mathrm{mo}$ ) and broccoli plants that had never been exposed to the virus. In other bioassays (Webb 1988), we found that first instars survived best on tender, succulent leaves; thus, we transferred them after the acquisition period to broccoli leaves held in water in florist's holders to reduce early mortality. All other larvae were transferred to broccoli leaves without water. Because the supply of control leaves (cabbage treated 2 mo earlier) was limited, we tested these at $28^{\circ} \mathrm{C}$ only. We exposed first, third, and fifth instars to treated leaves for $20-23 \mathrm{~h}$ at 16,22 , or $28^{\circ} \mathrm{C}$. Analysis of variance using arcsinetransformed percentage of infection and orthogonal contrasts were used to assess the effects of age and temperature and their interaction.

\section{Results}

In 1985, infected individuals were detected on the first day of sampling, $3 \mathrm{~d}$ after treatment (Fig. 1). The level of infection at $3 \mathrm{~d}$ in the oldest age class (larvae that had been in the late fourth and early fifth instars at the time of treatment) lagged significantly behind the average of the younger age classes $(t=-2.61, \mathrm{df}=6, P=0.04)$, but this difference disappeared at $4 \mathrm{~d}$ after treatment. The linear effect or rate of increase was greater (steeper) for the oldest population $(t=2.74, \mathrm{df}=6, P=$ 0.03 ) when compared with the average of the other two groups; the rate of increase for the intermediate (late second, early third instar when treated) and youngest classes (newly hatched when treated) differed by an insignificant amount. On the final day of sampling, when we had switched to wholeplant samples, the intermediate age class had a significantly higher level of infection than the youngest age class $(t=2.50, \mathrm{df}=6, P=0.05)$; the oldest age class, however, did not.

The initial pattern of disease was the same in 1986 (Fig. 2) as it was in 1985, perhaps because weather conditions (both temperature and rainfall) were the same in both years. Viral infections were first detected $3 \mathrm{~d}$ after treatment, and again, a lower proportion of the oldest class was judged to be infected on day $3(t=-8.6, \mathrm{df}=4, P=0.001)$. In 1986, however, the rate of increase in detectable infection for the intermediate age class was significantly greater than that for the youngest age group $(t=2.87, \mathrm{df}=4, P=0.046)$, and the final level of disease was greater as well $(t=2.52, \mathrm{df}=4, P$ $=0.06$ ), although this difference was not significant at $P=0.05$. For all age classes, peak levels of infection were lower in 1986 than in 1985.

Effect of Age and Temperature. The following orthogonal contrasts were used to examine the effects of age and temperature on infection: 16 versus the average of 22 and $28^{\circ} \mathrm{C}, 22$ versus $28^{\circ} \mathrm{C}$ 


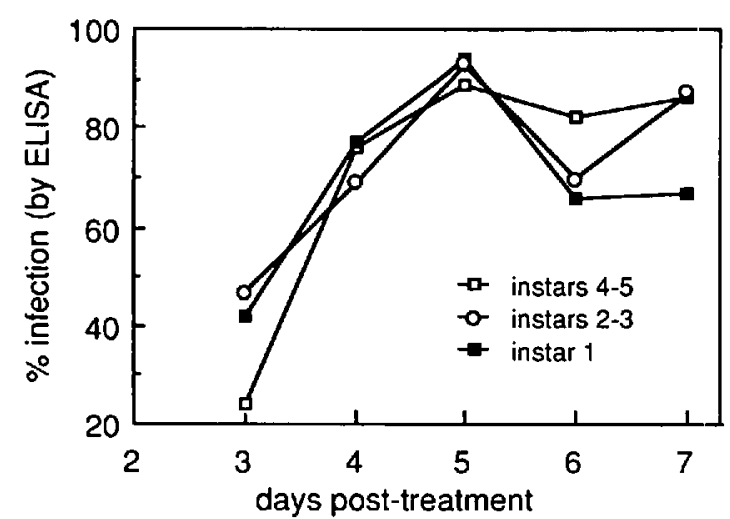

Fig. 1. Progress of epizootic of granulosis virus in three age classes of $A$. rapae. Larvae were collected beginning $3 \mathrm{~d}$ after treatment, August 1985.

(averaged across age), first instar versus the average of third and fifth instar, third versus fifth instar (averaged across temperature). In the first experiment, the level of disease was lower overall for larvae given access to leaves at $16^{\circ} \mathrm{C}$ compared with the average of the two higher temperatures (Fig. 3) $(t=-4.93, \mathrm{df}=13, P=0.0003)$. There was no significant difference in the proportion of diseased larvae at 22 and $28^{\circ} \mathrm{C}$. Averaged across temperature, a lower proportion of first instars ( $8 \%$ ) became infected compared with the average of the third and fifth instars (58\%). A higher proportion of third instars succumbed to virus than did fifth instars $(72$ versus $44 \%$ ). There was an interaction of age and temperature; third instars responded much more strongly to an increase in temperature from 16 to $22^{\circ} \mathrm{C}$ than did first and fifth instars. None of the larvae fed leaves from untreated plants became diseased.

In contrast, in the second experiment, all third and fifth instars and $27 \%$ of first instars fed leaves from plants treated 2 mo earlier but not re-treated (i.e., the check plants) became infected when given access at $28^{\circ} \mathrm{C}$. Even with this high level of contamination (results are not adjusted for mortality

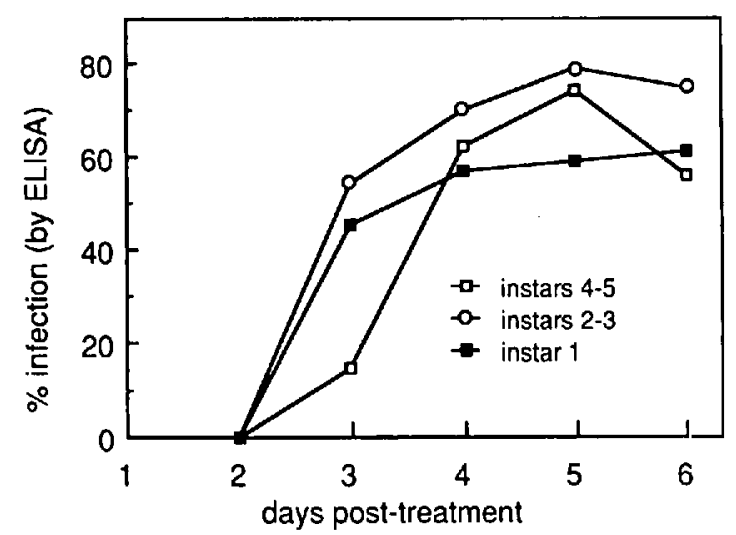

Fig. 2. Progress of epizootic of granulosis virus in three age classes of A. rapae. Larvae were collected beginning $2 \mathrm{~d}$ after treatment, August 1986.

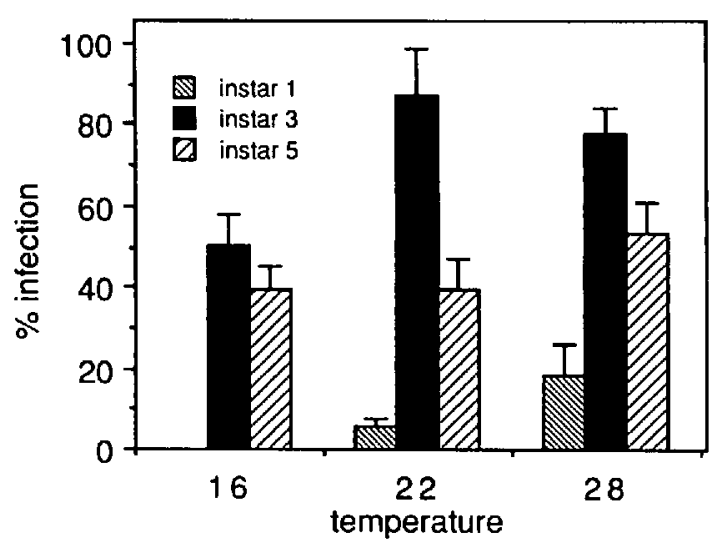

Fig. 3. Effect of temperature and age on level of infection among $A$. rapae larvae fed leaves from virustreated potted cabbage plants for $18 \mathrm{~h}$.

in the check plants), infection resulting from acquisition periods on re-treated plants at $16^{\circ} \mathrm{C}$ was less than that at 22 and $28^{\circ} \mathrm{C}(t=-5.23, \mathrm{df}=16$, $P=0.0001$ ), and the overall level of infection was less at 22 than at $28^{\circ} \mathrm{C}(t=-3.24$, df $=16, P=$ 0.005 ) (Fig. 4). Again, a lower proportion of first instars, averaged across temperature (77\%), became diseased compared with the average infection among third and fifth instars $(95 \%)(t=-6.19$, $\mathrm{df}=16, P=0.0001$ ). There were, however, no significant differences between third and fifth instars, and no interaction of age and temperature. None of the larvae fed untreated broccoli leaves became infected.

\section{Discussion}

The ELISA allowed us to follow epizootics directly before larvae died and disappeared from the population and before any healthy fifth instars pupated. We obtained a more dynamic picture of disease development in the different age classes

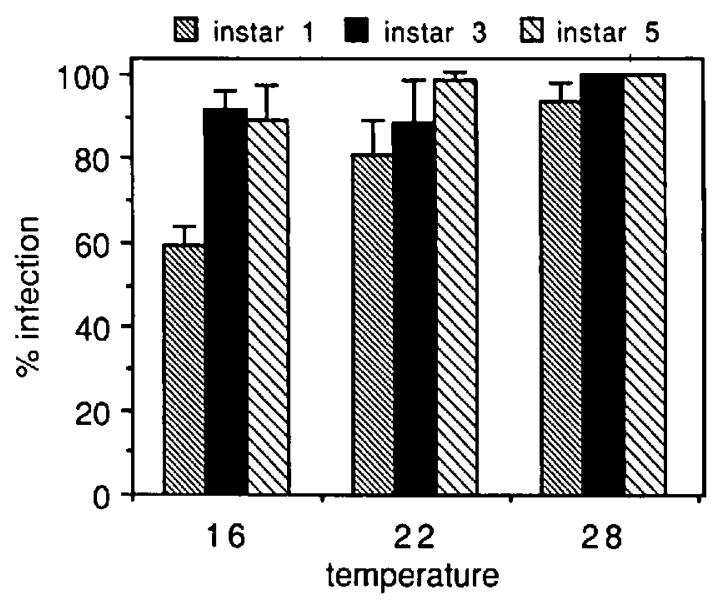

Fig. 4. Effect of temperature and age on level of infection among $A$. rapae larvae fed leaves from potted cabbage plants treated a second time with virus (second treatment 2 mo after the first). 
than if we had collected and reared insects from one sample, and we also avoided the problems and expense of rearing field-collected $A$. rapae larvae (Webb 1988). The incidence of infection with granulosis virus was not markedly different among different age classes of $A$. rapae, suggesting that the higher feeding rates of older larvae compensated for their reduced susceptibility to infection. Larvae that had hatched on the day of treatment had a lower final incidence of infection than larvae that had been in the second and third instars. First instars generally feed on the lower leaf surface and consume very little foliage (Tatchell 1981, Samson $\&$ Geier 1983); thus, they may escape infection because they fail to encounter any virus.

Detectable levels of disease developed more slowly in the oldest age class, indicating either that older larvae took longer to acquire lethal doses, or that, in individual larvae, infections progressed at a slower rate because these larvae ingested less effective doses. A constant exposure to low doses of virus over a long time period could lead to a high (but less sychronized) incidence of infection. Laboratory studies also have shown slower development of disease in larvae that became infected when fed low concentrations of virus than those fed at high concentrations (Johnson 1980, Teakle et al. 1985a).

Bias in sampling may account for differences between 1985 and 1986, particularly on days 5 and 6 . In preliminary tests, we had found no difference in location on the plant of healthy and infected fourth and fifth instars, but this may not be the case for younger larvae. As A. rapae larvae develop, they move from the outer leaves of cabbage in toward the head (Samson \& Geier 1983, Hoy \& Shelton 1987). Infected larvae develop more slowly than healthy larvae (usually molting only once more before death), even before symptoms of disease appear (Tatchell 1981); this may have resulted in a difference in spatial distribution of healthy and diseased larvae on the plant, particularly for the youngest age class.

Laboratory tests with potted cabbage (treated in the same manner as those in the field trials) gave the same results as those obtained in the field. The youngest larvae were least likely to ingest lethal doses of virus even when concentrations of virus were very high. In the first experiment, more third instars, intermediate in feeding rate and susceptibility, became infected than either first or fifth instars.

Plants used in the second experiment had been exposed to wild $A$. rapae adults after being treated the first time. Enough larvae became infected and died on these plants to increase the virus load dramatically in the 2 mo between the first and second applications, even though these plants were outside where they were exposed to sunlight and rain. Differences in incidence of infection between third and fifth instars disappeared at this higher concentration of virus. In both experiments, lower tem- peratures, which decrease feeding rates (Tatchell 1981), also decreased infection levels, particularly at $16^{\circ} \mathrm{C}$.

Our results suggest that, for effective control of A. rapae, applications of granulosis virus should be aimed at second and third instars. These larvae will die before reaching the fifth, most damaging, instar (Tatchell 1981) and are more likely to become infected than first instars. The high feeding rate of fifth instars increases the probability that they will ingest a lethal dose of virus; this also results in unacceptable damage to cabbage. Much more needs to be done to confirm the relationship of virus concentration, spatial distribution of larvae, and feeding rates; our laboratory results indicate the complexity of the interaction of these factors.

\section{References Cited}

Clark, M. F. \& A. N. Adams. 1977. Characteristics of the microplate method of enzyme-linked immunosorbent assay for the detection of plant viruses. J. Gen. Virol. 34: 475-483.

David, W. A. L. 1975. The status of viruses pathogenic for insects and mites. Annu. Rev. Entomol. 20: 97117.

Evans, H. F. 1986. Ecology and epizootiology of baculoviruses, pp. 89-132. In R. R. Granados \& B. A Federici [eds.], The biology of baculoviruses, vol. II. CRC, Boca Raton, Fla.

Harper, J. D. 1973. Food consumption by cabbage loopers infected with nuclear polyhedrosis virus. J. Invertebr. Pathol. 21: 191-197.

Hoy, C. W. \& A. M. Shelton. 1987. Feeding response of Artogeia rapae (Lepidoptera: Pieridae) and Trichoplusia ni (Lepidoptera: Noctuidae) to cabbage leaf age. Environ. Entomol. 16: 680-682.

Jaques, R. P. 1977. Field efficacy of viruses infectious to the cabbage looper and imported cabbageworm on late cabbage. J. Econ. Entomol, 70: 111-118.

Johnson, D. W. 1980. Temperature dependent developmental models for the velvetbean caterpillar and an associated nucleopolyhedrosis virus. Ph.D. dissertation, University of Florida, Gainesville.

Kelsey, J. M. 1958. Control of Pieris rapae by granulosis viruses, N.Z. J. Agric. Res. 1: 778-782.

Payne, C. C., G. M. Tatehell \& C. F. Williams. 1981. The comparative susceptibilities of Pieris brassicae and $P$. rapae to a granulosis virus from $P$. brassicae J. Invertebr. Pathol. 38: 273-280.

Potter, M. F. \& T. F. Watson. 1983. Timing of nuclear polyhedrosis virus-bait spray combinations for control of egg and larval stages of tobacco budworm (Lepidoptera: Noctuidae). J. Econ. Entomol. 76: 446448.

Samson, P. R. \& P. W. Geier. 1983. Induction of crop damage by the cabbage white butterfly, Pieris rapae (Lepidoptera: Pieridae), on cabbage. Prot. Ecol. 5: 199-233.

SAS Institute. 1985. SAS user's guide: statistics, vers. 5 ed. SAS Institute, Cary, N.C.

Sears, M. K., R. P. Jaques \& J. E. Laing. 1983 . Utilization of action thresholds for microbial and chemical control of lepidopterous pests (Lepidoptera: Noctuidae, Pieridae) on cabbage. J. Econ. Entomol. 76 368-374. 
Tatchell, G. M. 1981. The effects of a granulosis virus infection and temperature on the food consumption of Pieris rapae (Lepidoptera: Pieridae). Entomophaga 26: 291-299.

Teakle, R. E., J. M. Jensen \& J. E. Giles. 1985a. Susceptibility of Heliothis armiger to a commercial nuclear polyhedrosis virus. J. Invertebr. Pathol. 46: 166-173.

Teakle, R. E., J. M. Jensen \& J. C. Mulder. $1985 b$. Susceptibility of Heliothis armiger (Lepidoptera: Noctuidae) on sorghum to nuclear polyhedrosis virus. J. Econ. Entomol. 78: 1373-1378.
Webb, S. E. 1988. Epidemiology of a granulosis virus: implications for microbial control of imported cabbageworm, Artogeia rapae (L.), in cabbage. Ph.D. dissertation, Cornell University, Ithaca, N.Y.

Wilson, F. 1960. The effectiveness of a granulosis virus applied to field populations of Pieris rapae (L.). Aust. J. Agric. Res. 11: 485-497.

Received for publication 21 July 1988; accepted 24 April 1989. 